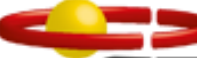

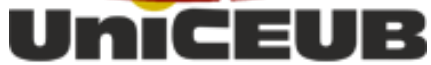 \\ Centro Universitárı de Brasílıa \\ CENTRO UNIVERSITÁRIO DE BRASÍLIA - UnICEUB \\ FACULDADE DE CIÊNCIAS DA EDUCAÇÃO E DA SAÚDE - FACES \\ PROGRAMA DE INICIAÇÃO CIENTÍFICA
}

LEANDRO PIN RANGEL

Relação entre a dureza do escoamento de áreas agrícolas e a dureza da água do córrego Sarandi - DF:

Um ensaio sobre a potencial influência desse parâmetro na composição de espécies aquáticas

BRASÍLIA-DF

2016 


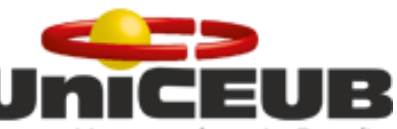 \\ Centro Unıversıtárıo de Brasílıa \\ LEANDRO PIN RANGEL}

Relação entre a dureza do escoamento de áreas agrícolas $\mathrm{e}$ a dureza da água do córrego Sarandi - DF:

Um ensaio sobre a potencial influência desse parâmetro na composição de espécies aquáticas

Relatório final de pesquisa de Iniciação Científica apresentado à Assessoria de Pós-Graduação e Pesquisa pela Faculdade de Ciências da Educação e da saúde - FACES

Orientação: Eduardo Cyrino de Oliveira Filho

BRASÍLIA-DF 2016 


\title{
RELAÇÃO ENTRE A DUREZA DO ESCOAMENTO DE ÁREAS AGRÍCOLAS \\ E A DUREZA DA ÁGUA DO CÓRREGO SARANDI - DF: UM ENSAIO SOBRE A POTENCIAL INFLUÊNCIA DESSE PARÂMETRO NA COMPOSIÇÃO DE ESPÉCIES AQUÁTICAS
}

\author{
Leandro Pin Rangel - UniCEUB, PIBIC-CNPq, aluno bolsista \\ Leandro.rangel5@gmail.com
}

Eduardo Cyrino Oliveira-Filho - UniCEUB, professor orientador

eduardo.cyrino@uniceub.br

A agua é um elemento se suma importância para a sobrevivência dos organismos. Todavia, o grande desperdício e a contaminação por atividades antrópicas estão prejudicando sua disponibilidade para uso e a biodiversidade dos ambientes aquáticos. Um dos parâmetros influenciados pela contaminação/escoamento antrópico é a dureza da água, refletida principalmente pelos elementos $\mathrm{Ca}$ e $\mathrm{Mg}$. Nesse contexto, o presente projeto teve por objetivo relacionar a dureza da água do escoamento superficial de áreas agrícolas com a dureza da água de um Córrego localizado abaixo da área monitorada, e discutir a possível influência desse escoamento na presença e sobrevivência de espécies aquáticas. Os resultados obtidos mostram que a dureza do escoamento variou de 12 no solo com pasto a 36 no solo com cana, durante o ano hidrológico de 2015/2016, e a dureza do córrego Sarandi, logo abaixo das calhas, variou de 2 no ponto cachoeira a 8 no mês de junho. Sobre esse aspecto a presença de organismos do zooplâncton nos pontos de coleta do córrego, evidenciou diferença entre espécies presentes nas áreas naturais do córrego e naquelas sob uso agrícola do solo. Todavia essa não pode ser relacionada com a dureza, tendo em vista a pequena variação desse parâmetro ao longo do córrego Sarandi. O resultado do levantamento de espécies no córrego, sugere a possibilidade de influência de lançamento de esgotos, todavia esse aspecto não foi devidamente avaliado. Como conclusão foi possível observar que o escoamento não influenciou a dureza da água no córrego que por sua vez não pode estar relacionada a composição de espécies aquáticas.

Palavras chave: Zooplâncton. Ecotoxicologia. Escoamento Superficial. Qualidade de agua. 


\section{Sumário}

1. Introdução

1.1. Problema de pesquisa

1.2. Justificativa

1.3. Objetivo geral

2. Fundamentação teórica

3. Metodologia

4. Resultados

5. Conclusões

6. Referências bibliográficas 


\section{INTRODUÇÃO}

\section{1 problema da pesquisa}

O escoamento superficial é a etapa do ciclo hidrológico caracterizada pelo deslocamento da água na superfície da terra. Vários fatores podem influenciar nesse processo tais como o relevo, a cobertura vegetal e a intensidade, duração e frequência das chuvas. A água escoada pela superfície do solo é fator importante para os processos de erosão, transporte e deposição de sedimentos e nutrientes pelas vertentes e corpos hídricos de bacias hidrográficas (VANLANDEGHEM et al., 2012). Dentre os vários nutrientes presentes na água de escoamento, destacam-se o cálcio $(\mathrm{Ca})$ e o magnésio $(\mathrm{Mg})$, que possuem relação direta com a dureza da água. A dureza da água é uma propriedade resultante principalmente, da dissolução de minerais presentes no solo e em rochas, mas também pode ser influenciada por ações antrópicas de diversas origens, como a agricultura e a urbanização (WURTS, 1993).

Muitos organismos aquáticos, como crustáceos e moluscos, dependem diretamente da dureza da água para a sua sobrevivência e reprodução (ROBERTSON, 1941; YOUNG, 1975; MEYRAN, 1998).

Desse modo, o presente trabalho tem como objetivo relacionar a dureza da água do escoamento superficial em áreas agrícolas com diferentes usos do solo com a dureza da água de um Córrego que fica abaixo dessa área, e discutir acerca da possível influência desse escoamento na presença e sobrevivência de espécies aquáticas.

\subsection{Justificativa}

O histórico de evolução do desmatamento e fragmentação dos ecossistemas no Bioma Cerrado está atrelado à história da evolução da produção agropecuária na região. Com a intensificação da produção agrícola, no final da década de 1970, grandes áreas de mata ripária (e outras formações 
florestais) foram derrubadas para a produção de grãos, pastagens e hortaliças (FONSECA et al., 2001).

A supressão da zona ripária pode ocasionar, dentre outros impactos, a erosão do solo (que constitui o mais importante meio de transporte dos nutrientes para os mananciais de água), e a diminuição da capacidade de 'tamponamento' de poluentes de fonte difusa pelos corpos hídricos, uma vez que a presença da vegetação reduz a infiltração de nutrientes para eles (LEE et al., 2003; CLINTON, 2011; BAKER et al., 2007).

No processo de contaminação dos recursos hídricos, a prática da agropecuária representa um risco no que se refere à contaminação microbiológica e à utilização de agrotóxicos e fertilizantes, que podem atingir aos rios por meio do escoamento superficial da água de chuva (OLIVEIRA-FILHO; LIMA, 2002).

Para detectar problemas relacionados à poluição de ambientes aquáticos por fonte de poluição difusa (escoamento superficial), a adoção de métodos químicos, físicos e biológicos é considerada uma estratégia de avaliação. A comparação entre a qualidade da água de escoamento em área com e sem a mata ripária, visa qualificar o papel da vegetação e fornecer subsídios para ações de restauração e preservação desses ambientes.

\subsection{Objetivo Geral}

Relacionar a dureza da água do escoamento superficial em áreas agrícolas com diferentes usos do solo com a dureza da água de um Córrego que fica abaixo dessa área, e discutir acerca da possível influência desse escoamento na presença e sobrevivência de espécies aquáticas.

\subsection{Objetivos Específicos}

a. Coletar amostras do escoamento das calhas e dos pontos do córrego Sarandi;

b. Realizar análises de dureza total, e dos íons $\mathrm{Ca} 2+$ e $\mathrm{Mg} 2+$ nas amostras das águas coletadas no rio e nas calhas; 
c. Comparar a dureza do escoamento com a dureza da água do córrego;

d. Avaliar a potencial contribuição do escoamento na composição de espécies do córrego.

\section{FUNDAMENTAÇÃO TEÓRICA}

A prática de agricultura e pecuária no Cerrado vem ganhando destaque nas últimas décadas, contudo, a conservação dos diferentes ecossistemas naturais do bioma (incluindo as matas ripárias) não tem acompanhado esse progresso (ALHO, 2005). No Brasil, assim como na maioria dos países, a degradação de áreas ripárias sempre foi e continua sendo fruto da expansão desordenada de fronteiras agrícolas ou de práticas agropecuárias inadequadas (RODRIGUES; GANDOLFI, 2000).

A agricultura, como o maior usuário de água doce a nível mundial e como uma das causadoras de degradação, seja de recursos vegetais, quanto de recursos hídricos superficiais e subterrâneos, contribui para as preocupações a respeito das implicações globais sobre a qualidade da água e da diminuição das reservas florestais.

As matas ripárias desempenham funções ecológicas, sociais e econômicas importantes, entre elas a manutenção dos leitos dos rios, proteção das nascentes, conservação do solo contra erosão e empobrecimento, preservação do patrimônio genético, manutenção de condições favoráveis à fauna, entre outros. Porém, o papel mais importante é a manutenção dos recursos hídricos (AQUINO; VILELA, 2008).

Devido a essa importância, essa vegetação foi contemplada em lei no Código Florestal de 1965 (BRASIL, 1965), que especificou larguras mínimas de proteção para diferentes dimensões dos corpos hídricos. A faixa de mata ciliar regulada pela lei recebe a denominação de Área de Preservação Permanente (APP), sendo seu uso vetado para qualquer fim que não seja preservação ambiental (MARTINI; TRENTINI, 2011). 
O antigo Código Florestal sofreu diversas modificações, com alterações dos limites das APPs nas últimas décadas. A Lei n. 7.511, de 1986, aumentou a largura da mata, após desastres naturais que ocorreram na época e em 1989, a largura das APPs ripárias foi alterada pela Lei n. 7.830, que manteve as faixas de $30 \mathrm{~m}$ (para cursos d'água de menos de $10 \mathrm{~m}$ de largura) e de $50 \mathrm{~m}$ (para os cursos d'água entre 10 a $50 \mathrm{~m}$ de largura), mas alterou as demais faixas, que haviam sido estabelecidas pela Lei n. 7.511 (SAUER; FRANÇA, 2012).

O Novo Código Florestal publicado em 25 de maio de 2012 gerou polêmica no meio científico, sendo sancionado com 12 vetos e diversas alterações. No texto atual a principal modificação relativa às matas ripárias prevê $30 \mathrm{~m}$ para matas ripárias em rios de até 10 metros de largura; quando houver área consolidada em APP de rio de até $10 \mathrm{~m}$ de largura, reduz-se a largura mínima da mata para $15 \mathrm{~m}$. Cinquenta metros nas margens de rios entre $10 \mathrm{e}$ $50 \mathrm{~m}$ de largura, e ao redor de nascentes de qualquer dimensão. Mil metros nas margens de rios entre 50 e $200 \mathrm{~m}$ de largura. Duzentos metros para rios entre 200 e $600 \mathrm{~m}$ de largura. Quinhentos metros nas margens de rios com largura superior a $600 \mathrm{~m}$. Cem metros nas bordas de chapadas (BRASIL, 2012).

Tais mudanças no Código Florestal brasileiro acerca da preservação e restauração de áreas de mata ripária demandam cada vez mais estudos sobre a importância desses ambientes para a manutenção da qualidade dos corpos hídricos.

Nesse sentido, são necessários conhecimentos sobre a influência das áreas de agricultura nos recursos hídricos e manutenção da vida aquática, visando à geração de dados que possam esclarecer dúvidas e mostrar efetivamente as consequências do uso do solo e as possíveis perturbações ambientais ocasionadas.

Dados recentes mostram que a dureza da água em áreas de nascente do Cerrado, incluindo o córrego Sarandi, é muito baixa. Todavia, os mesmos estudos mostram que em áreas posteriores à nascente, a dureza é consideravelmente aumentada (MUNIZ et al., 2011). Outros estudos sugerem que a manutenção da vida de algumas espécies em água com baixa dureza é praticamente inviável (GREENAWAY, 1985; HARMON, 2003; KIEHN ET AL., 
2004), e nesse caso se enquadra o córrego Sarandi em sua nascente, onde a dureza não permite a sobrevivência e a reprodução de gastrópodes aquáticos da espécie Biomphalaria glabrata (OLIVEIRA-FILHO et al., 2014).

\section{METODOLOGIA}

\subsection{Localização e descrição da área de estudo}

Para a realização do presente estudo, serão utilizados dados obtidos em calhas de monitoramento da enxurrada construídas em área de campo experimental da Embrapa Cerrados em Planaltina - DF. Além disso, será realizado monitoramento da qualidade da água (dureza) em 6 pontos do Córrego Sarandi, visando a comparação com os dados obtidos nas calhas construídas sob a influência de quatro diferentes coberturas do solo (pasto, cana, soja e solo exposto).

A Bacia do Córrego Sarandi está localizada na parte norte do Distrito Federal, entre as cidades de Sobradinho e Planaltina, com exutório nas

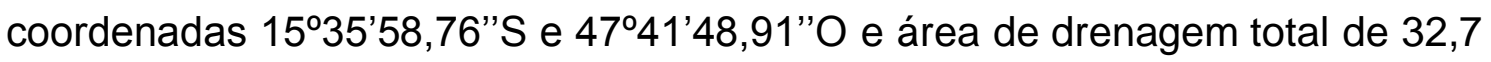
$\mathrm{km}^{2}$ (LIMA et al. 2013) (Figura 1).

A área caracteriza-se por ser uma área que sofre fortes influências de loteamentos e de atividades agrícolas desenvolvidas (CARVALHO, 2005; ASSIS et al., 2013).

Figura 1. Localização da Bacia Experimental do Córrego Sarandi no Distrito Federal. 


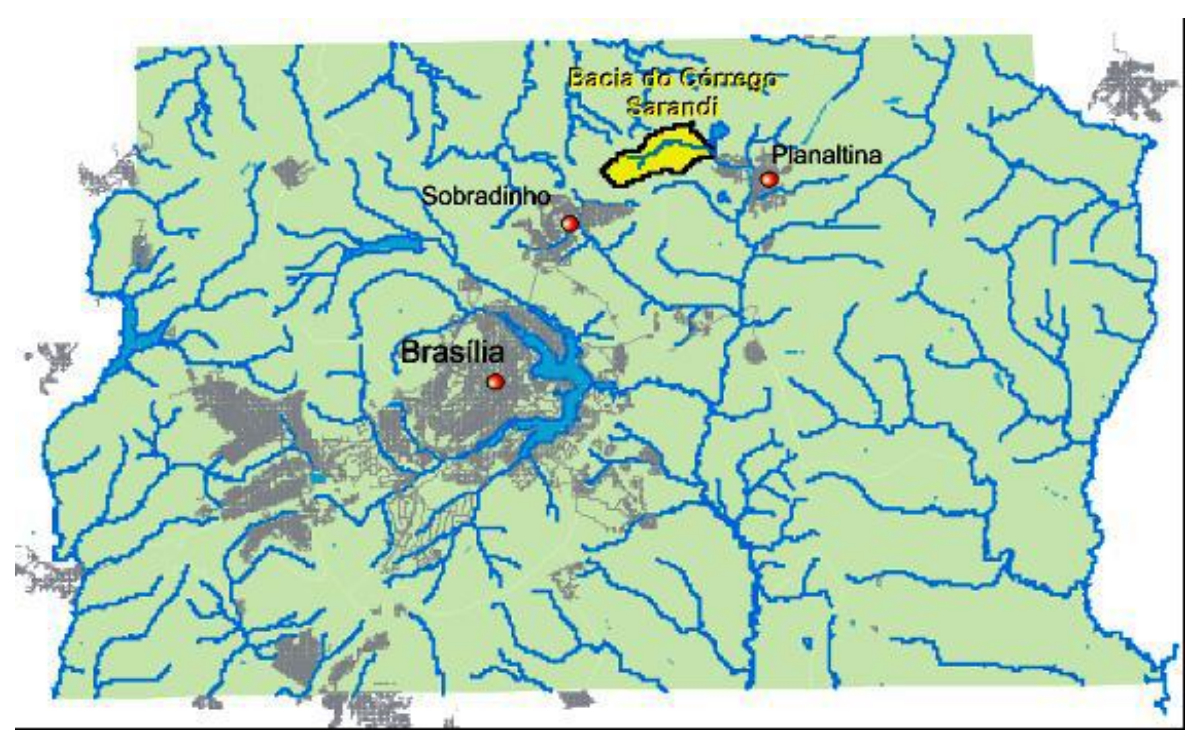

Fonte: Lima et al. (2013).

\subsection{Coletas das amostras nas calhas}

As calhas foram construídas em chapa galvanizada reforçada com cantoneiras 1 "x $1 / 8$, sendo a estrutura de contorno e o "bico coletor" da calha preparados/confeccionados no Laboratório de Máquinas da Embrapa Cerrados. A água escoada é armazenada em caixas d'água de polietileno com capacidade de 250 L. Além disso, foram instalados pluviógrafos para coleta de dados de precipitação.

As coletas das amostras de escoamento superficial ocorrerão mensalmente para a obtenção de dados de diferentes períodos de clima.

$\mathrm{Na}$ Figura 2 é apresentado um resumo fotográfico das etapas de construção e de monitoramento nas calhas de Wischmeier instaladas na Embrapa Cerrados.

Figura 2. Etapas da construção das calhas de Wischmeier na Embrapa Cerrados, até o monitoramento da quantidade de água escoada e da coleta de amostras para análises da qualidade da água e da carga de sedimentos. 


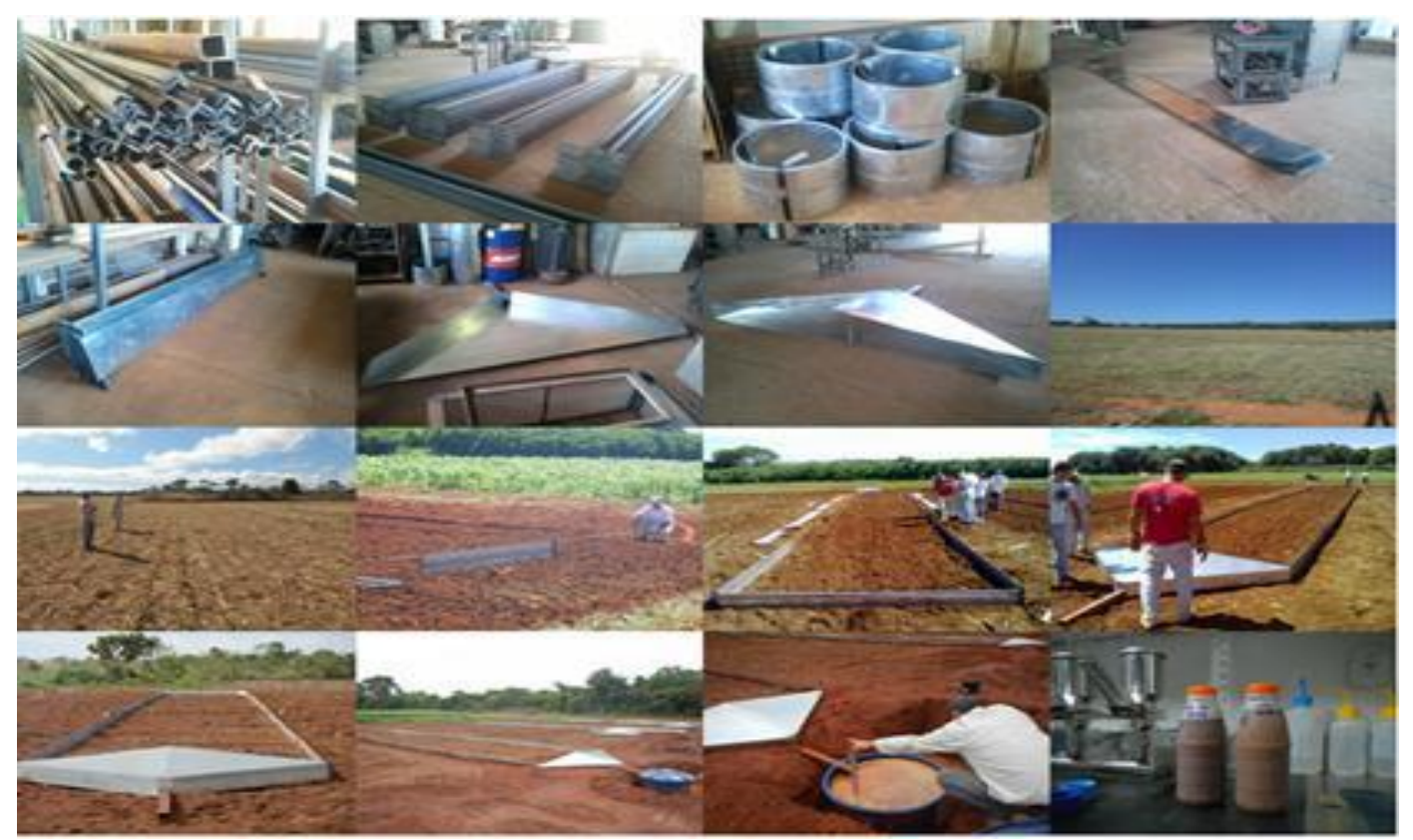

Fonte: Lima et al. (2013)

\subsection{Coletas das amostras no córrego Sarandi}

O córrego Sarandi, localizado no Distrito Federal, é afluente da margem direita do ribeirão Mestre d'Armas, que deságua no rio São Bartolomeu, tributário da bacia do rio Paraná. Grande parte da bacia ainda é coberta por vegetação natural de Cerrado, estando o restante submetido à influência de loteamentos e de atividades agropecuárias.

As coletas serão realizadas mensalmente ou mais em caso de eventos extremos de chuva. Os pontos de coleta no Córrego Sarandi foram definidos de acordo com as diferenças entre as várias ocupações do solo na região e são apresentados na figura 3, e a descrição dos pontos é apresentada no quadro 1. 
Figura 3 - Apresentação dos pontos de coleta no Córrego Sarandi.

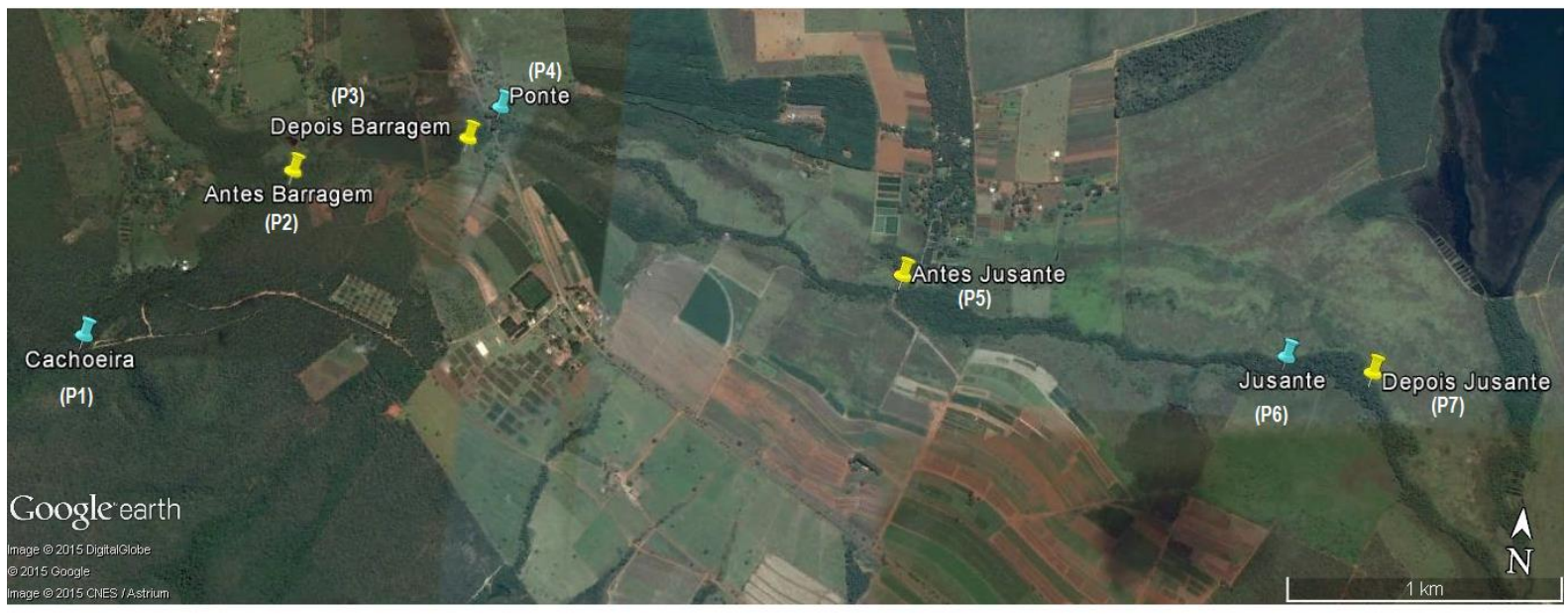

Quadro 1 - Descrição dos pontos de coleta de água no Córrego Sarandi.

\begin{tabular}{|c|c|c|}
\hline Sigla & Nome do ponto & Coordenadas \\
\hline P1 & Cachoeira & $\mathrm{S} 15^{\circ} 35^{\prime} 43,0^{\prime \prime} \mathrm{W} 47^{\circ} 44^{\prime} 46,4^{\prime \prime}$ \\
\hline P2 & Antes da Barragem & $\mathrm{S} 15^{\circ} 35^{\prime} 15.1^{\prime \prime} \mathrm{W} 47^{\circ} 44^{\prime} 02.1^{\prime \prime}$ \\
\hline P3 & Depois da Barragem & $\mathrm{S} 15^{\circ} 35^{\prime} 15.0^{\prime \prime} \mathrm{W} 47^{\circ} 44^{\prime} 02.0^{\prime \prime}$ \\
\hline P4 & Ponte & $\mathrm{S} 15^{\circ} 35^{\prime} 10,9^{\prime \prime} \mathrm{W} 47^{\circ} 43^{\prime} 58,7^{\prime \prime}$ \\
\hline P5 & Antes Jusante & $\mathrm{S} 15^{\circ} 35^{\prime} 28.0^{\prime \prime} \mathrm{W} 47^{\circ} 44^{\prime} 05.9^{\prime \prime}$ \\
\hline P6 & Jusante & $\mathrm{S} 15^{\circ} 35^{\prime} 33,9^{\prime \prime} \mathrm{W} 47^{\circ} 42^{\prime} 17,1^{\prime \prime}$ \\
\hline P7 & Depois do Jusante & $\mathrm{S} 15^{\circ} 35^{\prime} 35.5^{\prime \prime} \mathrm{W} 47^{\circ} 42^{\prime} 06.9^{\prime \prime}$ \\
\hline
\end{tabular}




\subsection{Análises físico-químicas}

As análises físico-químicas e microbiológicas da água objetivam identificar e quantificar elementos e espécies iônicas presentes no ambiente e associar os efeitos de suas propriedades às questões ambientais, permitindo a compreensão dos processos naturais ou alterações no meio ambiente (PARRON et al., 2011).

Para cada amostra coletada serão realizadas determinações dos parâmetros, temperatura, oxigênio dissolvido (OD), turbidez, condutividade, $\mathrm{pH}$ e dureza da água. Os parâmetros temperatura, oxigênio dissolvido, condutividade e pH serão determinados com a utilização do medidor multiparâmetros sension156 HACH. A turbidez será medida em laboratório por meio do turbidímetro portátil Hanna HI 93703, e a dureza da água será avaliada por meio do método titulométrico com EDTA-Na (mg/L de CaCO3) (ABNT, 1993).

Tais análises serão realizadas com as amostras das calhas e da água do córrego.

\section{RESULTADOS E DISCUSSÕES}

Os resultados dos parâmetros químicos analisados nas amostras do Córrego Sarandi e os dados de dureza das calhas analisadas estão expressos nos gráficos 1, 2, 3 e 4

\subsection{Dureza do córrego Sarandi}

As amostras de agua nos meses analisados não apresentam variação significativa de dureza como mostra o gráfico 1, os picos de junho e outubro onde foi detectado a maior dureza com o valor de 5,0 mg. $\mathrm{L}^{-1}$ de $\mathrm{CaCO} 3$ foi relacionado a presença de chuvas esporádicas. 


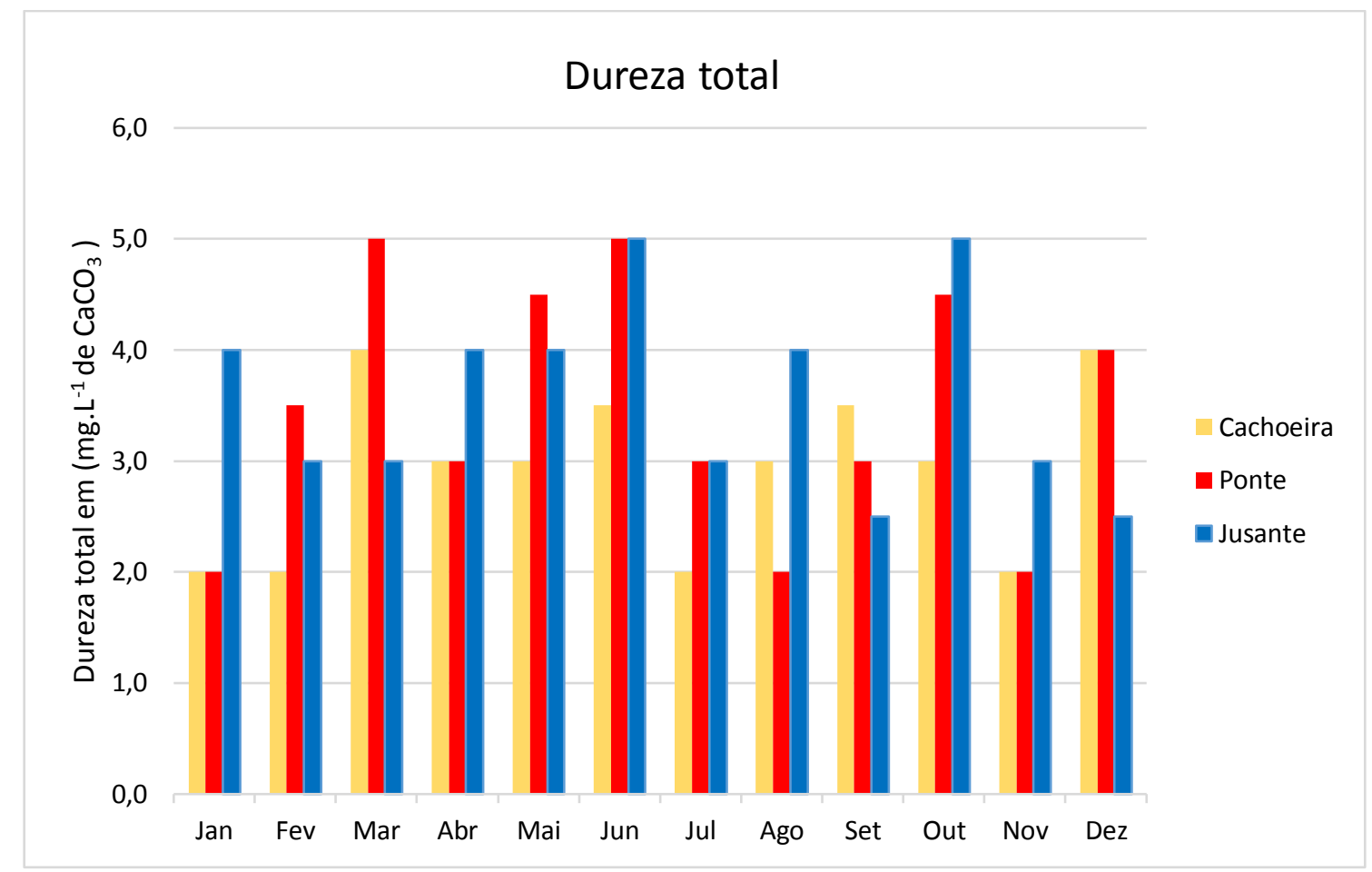

Gráfico 1. Valores de dureza total em $\mathrm{mg}^{\mathrm{L}{ }^{-1}}$ de $\mathrm{CaCO}_{3}$ das amostras de água superficial do Córrego Sarandi.

O grau de dureza total da água - definido principalmente pelo teor de íons cálcio e de magnésio - pode influenciar significativamente a sensibilidade de organismos, além disso, deve-se considerar também que o cálcio é um elemento essencial para o desenvolvimento corporal de peixes e crustáceos (KNIE; LOPES, 2004).

\subsection{Dureza das calhas}

As amostras de agua das calhas, não apresenta valores significativos de variação de dureza como mostra o gráfico 2, onde apenas no 2 semestre de 2015 (início do período chuvoso) foi detectado uma dureza com o valor de 36,0 mg. $\mathrm{L}^{-1}$ de $\mathrm{CaCO}_{3}$. O solo com uso de pasto na sede apresentou o maior valor de 36,0 mg. $\mathrm{L}^{-1}$ de $\mathrm{CaCO}_{3}$ e o menor valor no também com o solo com pasto na serra com o índice de $12,0 \mathrm{mg} \cdot \mathrm{L}^{-1}$ de $\mathrm{CaCO}_{3}$ 


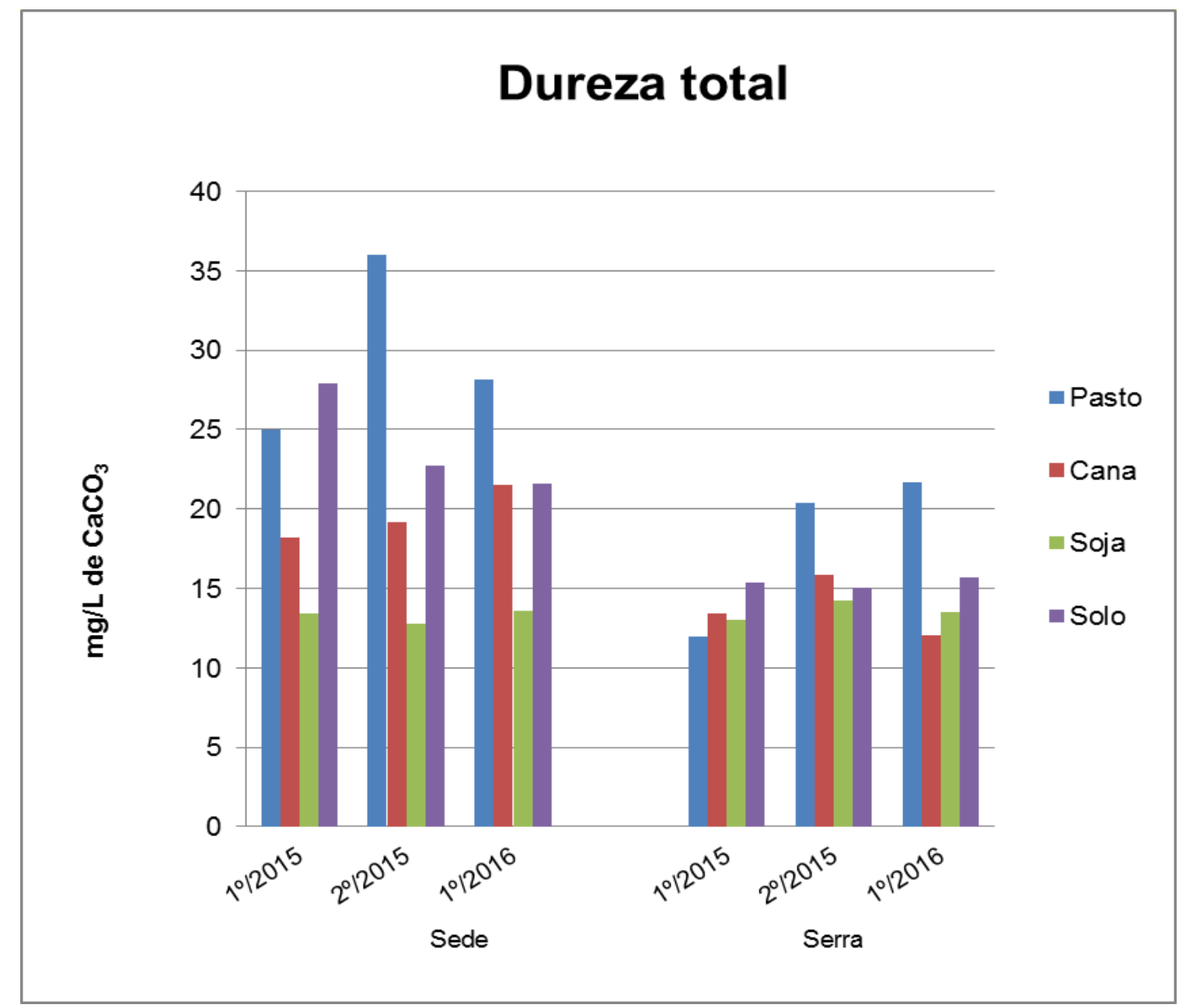

Gráfico 2. Valores de dureza total em $\mathrm{mg}^{\mathrm{L}}{ }^{-1}$ de $\mathrm{CaCO}_{3}$ das amostras coletadas nas calhas de Wischmeier

\subsection{Análises biológicas}

\subsubsection{Coliformes totais e termotolerantes}

O Gráfico 3 e 4 mostram o número mais provável (NMP) de coliformes totais e termotolerantes obtidos em $100 \mathrm{~mL}$ de amostras de agua do Córrego Sarandi no período de 1 ano e mostra as áreas vulneráveis com relação a este aspecto 


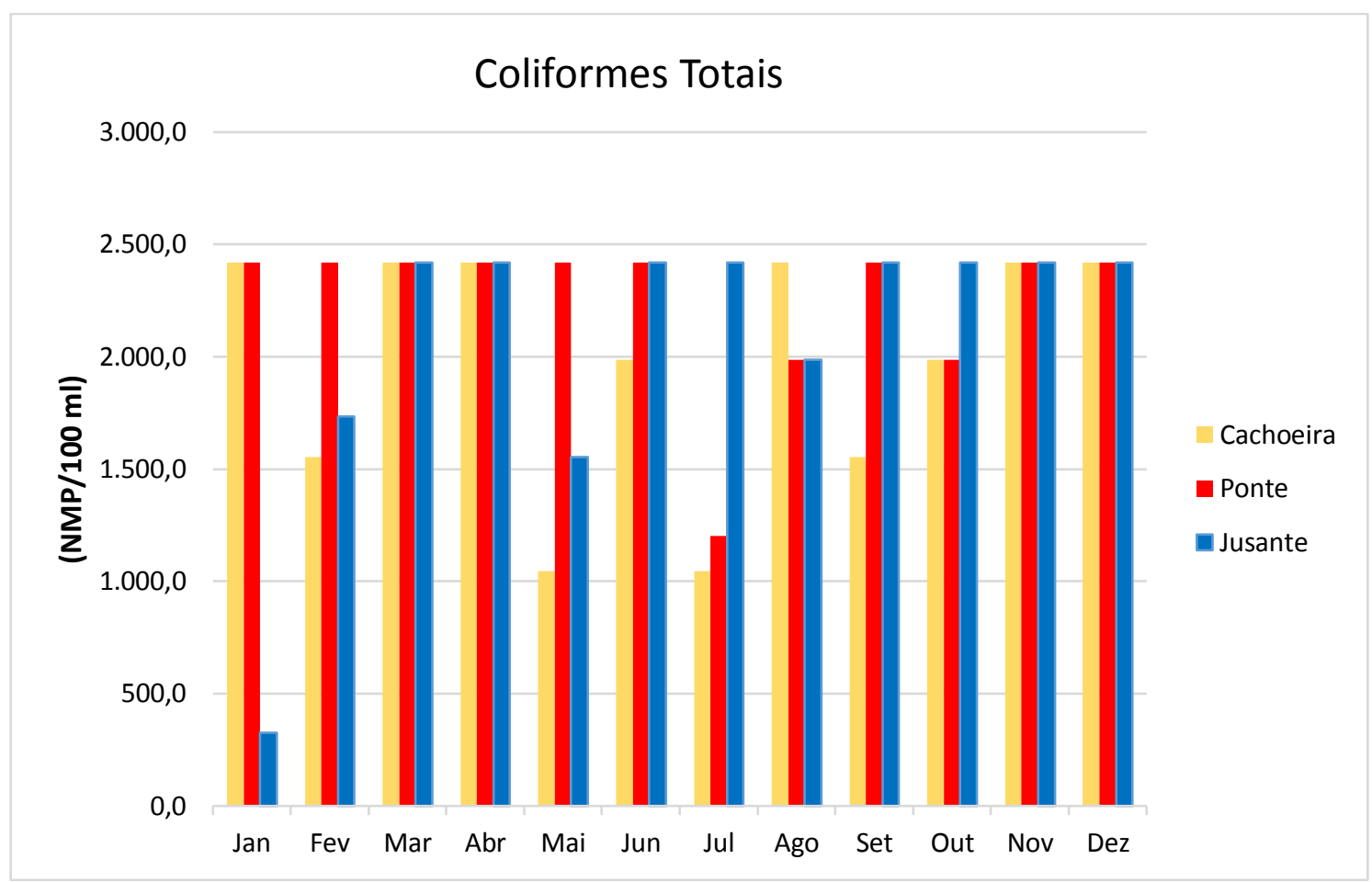

Gráfico 3. Número Mais Provável de coliformes totais em $100 \mathrm{~mL}$ das amostras de água do Córrego Sarandi.

As analises dos parametros microbiologicas apresentam um alto indice de coliformes totais durante todos os meses da amostragem (>2.419,6 NMP/100 $\mathrm{ml}$ ), contudo os índices variaram na jusante em janeiro com o valor mínimo de (325,5 NMP/100 mL) em maio na cachoeira (1046,2 NMP/100 mL) e na ponte no mês de julho (1203,3 NMP/100 mL) 


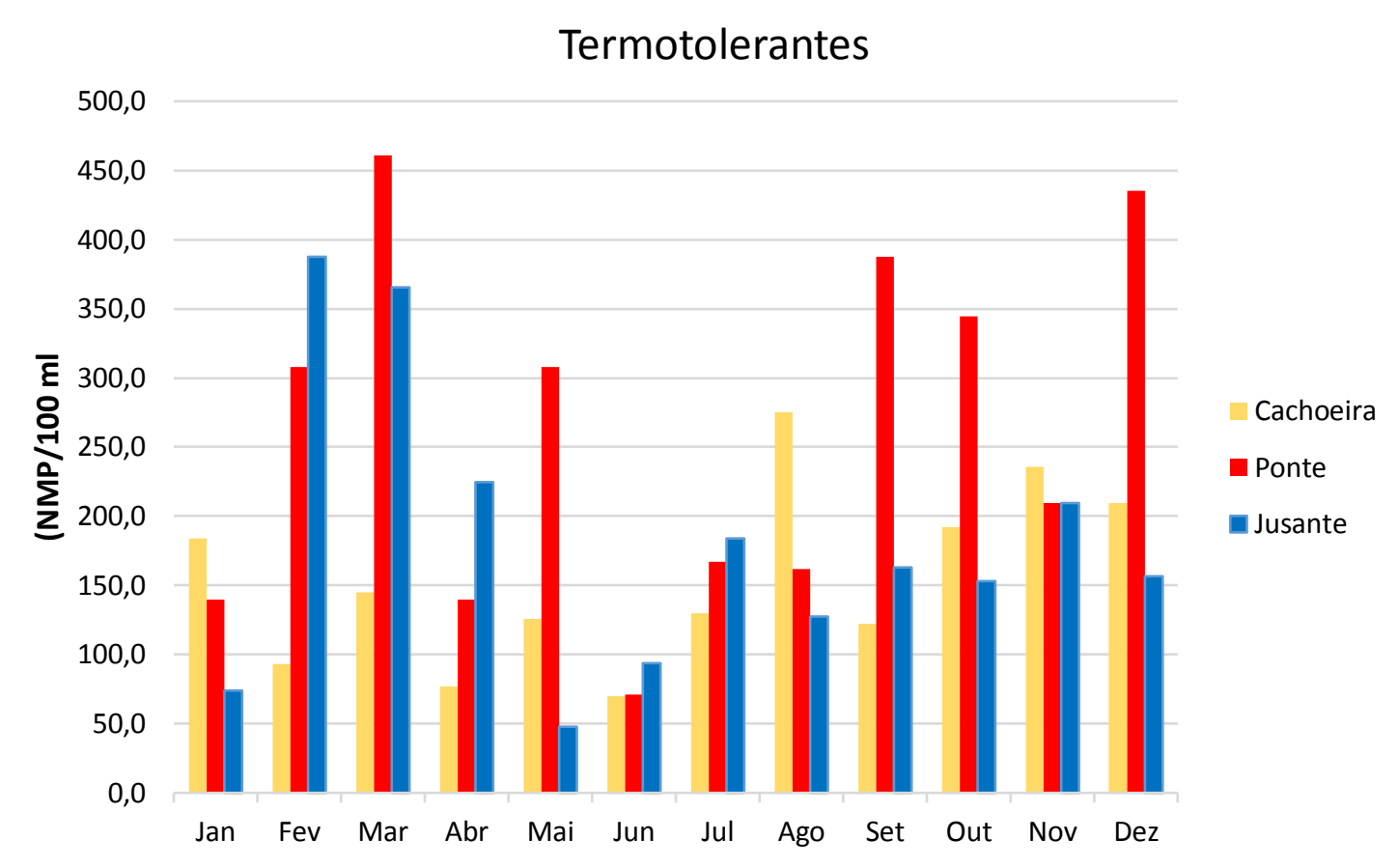

Gráfico 4. Número Mais Provável de coliformes termotolerantes em $100 \mathrm{~mL}$ das amostras de água do Córrego Sarandi.

Segundo a Resolução CONAMA № 357/05, a água para o uso de recreação de contato secundário não deverá ser excedido um limite de $2500 \mathrm{NMP} / 100 \mathrm{ml}$ em $80 \%$ ou mais de pelo menos 6 amostras. Para dessedentação de animais criados confinados não deverá ser excedido o limite de $1000 \mathrm{NMP} / 100 \mathrm{ml}$ em $80 \%$ ou mais de pelo menos 6 amostras.

O significado da presença de coliformes termotolerantes em um corpo d'água indica que há contaminação por bactérias de origem fecal e, portanto este corpo está em condição higiênica insatisfatória (SILVA; BRINGEL, 2007). Portanto amostras, contudo, indicam a possível atividade antrópica ao longo do rio, visto que a agua mesmo estando dentro dos limites das CONAMA, ainda apresenta uma quantidade significativa de coliformes termotolerantes.

\subsubsection{Zooplâncton}

A contagem de zooplâncton mostra uma pequena variedade de indivíduos nadantes (Cladóceros, Copépodes e rotíferos) e uma presença maior de indivíduos pouco nadantes como as tecamebas como visto no quadro 2 , com 
exceção da ponte onde o ambiente aquático é lótico e há a presença de ações antrópicas aumentando assim a quantidade de indivíduos por $\mathrm{m}^{3}$ de agua. Não foi possível fazer uma análise relacionada a dureza, pois a biodiversidade aquática se manteve com pouca variação.

Quadro 2. Número de indivíduos contados de cada táxon por metro cubico de agua.

\begin{tabular}{|l|r|r|r|}
\hline \multicolumn{1}{|c|}{ Táxon } & $\begin{array}{c}\text { Soma de indivíduos } \\
\text { pôr } \mathrm{m}^{3} \text { na Cachoeira }\end{array}$ & $\begin{array}{c}\text { Soma de indivíduos pôr } \mathrm{m}^{3} \\
\text { da Ponte }\end{array}$ & $\begin{array}{c}\text { Soma de indivíduos pôr } \\
\mathrm{m}^{3} \text { do Jusante }\end{array}$ \\
\hline Cladócero & 0 & 100 & 0 \\
\hline Copépode & 50 & 293,75 & 625 \\
\hline Rotífero & 125 & 7656,25 & 125 \\
\hline Tecameba & 206,25 & 475 & 1000 \\
\hline
\end{tabular}

\section{Conclusão}

De acordo com os resultados obtidos durante o estudo, verificou-se que a dureza do córrego Sarandi não obteve diferenças significativas e pouco variou ao longo do rio. As calhas de monitoramento mostraram que o escoamento pouco afetou a dureza do rio mesmo em períodos de chuva.

$\mathrm{Na}$ cachoeira, apresentou a menor dureza e o ambiente mais lênticos, com pouca aparição de indivíduos por coleta devido as características da agua que dificulta a aparição de uma biodiversidade maior.

A ponte apresentou a menor qualidade na agua, principalmente com relação aos parâmetros de coliformes aumentando assim a dureza da agua, mas apresenta uma grande variedade biológica visto que o ambiente e lótico. Esses resultados estão associados a atividades antrópicas observadas no lugar de coleta.

No Jusante apresentou uma baixa nos índices de coliformes e a mudança do ambiente aquático, que voltou a ser lênticos, com que não teve variação significativa na dureza da agua e os biodiversidade diminui. 


\section{REFERÊNCIAS BIBLIOGRÁFICAS}

ABNT (Associação Brasileira de Normas Técnicas). Água - Determinação da dureza total - Método titulométrico do EDTA-Na método de ensaio. NBR 12621. Rio de Janeiro: ABNT, Brasil. 1992.

ALHO, C. J. R. Desafios para a conservação do Cerrado, em face das atuais tendências de uso e ocupação. In: SCARLOT, A.; SOUSA-SILVA, J. C.; FELFILI, J. M. (Ogs.). Cerrado: ecologia, biodiversidade e conservação. Brasília: Ministério do Meio Ambiente, p. 369-381, 2005.

AQUINO, F.G.; VILELA, M.F. Importância das matas ripárias. 2008. Artigo em Hypertexto. Disponível em: <http://www.infobibos.com/Artigos/2008_4/matas/index.htm>. Acesso em: 23/02/2013.

ASSIS, T. Dinâmica da Cobertura da Terra da Bacia do Sarandi (DF) através de análise multitemporal e multisensor. Monografia (Gestão Ambiental), 35f. FUP/UNB, Brasília. 2013.

BAKER, M. E.; WELLER, D. E.; JORDAN, T. E. Effects of stream map resolution on measures of riparian buffer distribution and nutrient retention potential. Landscape Ecology, v. 22, p. 973-992, 2007.

BRASIL. LEI № 12.651, DE 25 DE MAIO DE 2012. Institui o Novo Código Florestal. Publicado no D.O.U. de 26 de maio de 2012.

BRASIL. LEI № 4.771, DE 15 DE SETEMBRO DE 1965. Institui o Código Florestal. Publicado no D.O.U. de 16 de setembro de 1965.

CARVALHO, P.R.S. A expansão urbana na bacia do Ribeirão Mestre d'Armas (DF) e a qualidade da água. Estudos Geográficos, v. 3, p. 71-91, 2005.

CLINTON, B. D. Stream water responses to timber harvest: Riparian buffer width effectiveness. Forest Ecology and Management, v. 216, n. 6. p.979-988, 2011.

FONSECA, C.E.L.; RIBEIRO, J.F.; SOUZA, C.C.; REZENDE, R.P.; BALBINO, V.K. Recuperação da vegetação de matas de galeria: estudo de caso no Distrito Federal e entorno. In: RIBEIRO, J..F; FONSECA, C.E.L.; SILVA, J.C.S. (Ed.) Cerrado: caracterização e recuperação de matas de galeria. Planaltina: Embrapa Cerrados, p. 815-870, 2001.

GREENAWAY, P. Calcium balance and moulting in the crustacea. Biological Reviews, v. 60, p. 425-454. 1985.

HARMON, S.M.; SPECHT, W.L.; CHANDLER, G.T. A comparison of the daphnids Ceriodaphnia dubia and Daphnia ambigua for their utilization in routine toxicity testing in the southeastern United States. Archives of Environmental Contamination and Toxicology, v. 45, p. 79-85, 2003. 
KIEHN, L.; MUKAI, S.T.; SALEUDDIN, A.S.M. The role of calcium on protein secretion of the albumem gland in Helisomaduryi (Gastropoda). Invertebrate Biology, v. 123, n. 304-315, 2004.

KNIE, J.L.W; LOPES, E.W.B. Testes ecotoxicológicos: métodos, técnicas e aplicações. Florianópolis: GTZ/FATMA, 2004. 289 p.

LEE, K. H.; ISENHART, T. M.; SCHULTZ, R. C. Sediment and nutrient removal in an established multi-species riparian buffer. Journal of Soil and Water Conservation, v. 58, n. 1, p. 1-18, 2003.

LIMA, J.E.F.W. ; OLIVEIRA-FILHO, E. C.; MARTINS, P. R.; SILVA, F. D. M.; SOBRINHO, H.C.; ARAUJO, L. S.; OLIVEIRA, L.; RODRIGUES, N. G.; OLIVEIRA, N. B. Instalação de calhas de monitoramento da enxurrada para apoio a estudos hidrológicos no Bioma Cerrado. In: XX Simpósio Brasileiro de Recursos Hídricos, 2013, Bento Gonçalves. Anais do XX Simpósio Brasileiro de Recursos Hídricos. Porto Alegre: ABRH, 2013. v. 1, p. 1-8.

MARTINI, L.C.P.; TRENTINI, E.C. Agricultura em zonas ripárias do sul do Brasil: conflitos de uso da terra e impactos nos recursos hídricos. Revista Sociedade e Estado, v. 26, n.3, p. 613-630, 2011.

MEYRAN, J.C. Ecophysiological diversity of alpine populations of Gammarus lacustris in relation to environmental calcium. Freshwater Biology, v. 39, p. 4147, 1998.

MUNIZ, D.H.F.; MORAES, A.S.; CRUZ, C.J.D.; LIMA, J.E.F.W.; OLIVEIRAFILHO, E.C. Evaluation of water quality parameters for monitoring natural, urban, and agricultural areas in the Brazilian savanna. Acta Limnologica Brasiliensia, v. 23, p. 307-317, 2011.

OLIVEIRA-FILHO, E. C., LIMA, J. E. F. Potencial de impacto da agricultura sobre os recursos hídricos na região do Cerrado. Planaltina: Embrapa Cerrados, Série Documentos 56, 2002. 50 p.

OLIVEIRA-FILHO, E. C.; CAIXETA, N. R.; SIMPLICIO, N. C. S.; SOUSA, S. R.; ARAGÃO, T. P.; MUNIZ, D. H. F. Implications of water hardness in ecotoxicological assessments for water quality regulatory purposes: a case study with the aquatic snail Biomphalaria glabrata (Say, 1818). Brazilian Journal of Biology, v. 74, p. 175-180, 2014.

PARRON, L.M.; MUNIZ, D.H.F.; PEREIRA, C.M. Manual de procedimentos de amostragem e análise físico-química de água. Colombo: Embrapa Florestas, Série Documentos 219, 2011. 69 p.

ROBERTSON, J.D. The function and metabolism of calcium in the invertebrate. Biological Reviews, v. 16, p. 106-133, 1941.

RODRIGUES, R. R.; GANDOLFI, S. Conceitos, tendências e ações para a recuperação de florestas ciliares. In: RODRIGUES, R. R.; LEITÃO-FILHO, H. F. Matas ciliares: conservação e recuperação. São Paulo: Editora Universidade de São Paulo FAPESP, p.235-247, 2000. 
SAUER, S.; FRANÇA, F.C. Código Floreta, função socioambiental da terra e soberania alimentar. Caderno CRH, v. 25, n. 65, p. 285-307, 2012.

SILVA, G.C.; BRINGEL, J.M.M. Incidência de coliformes totais e Escherichia coli nas águas utilizadas para irrigação pela comunidade do município do LumiarMA. Revista Brasileira de Agroecologia, v. 2, n. 1, 2007. p. 599-603.

VANLANDEGHEM, M. M. et al. Spatial and temporal patterns of surface water quality and ichthyotoxicity in urban and rural river basin in Texas. Water Research, v. 46, p. 6638-6651, 2012.

WURTS, W. A. Understanding water hardness. World Aquaculture, v. 24, p. 18, 1993.

YOUNG, J. O. Preliminary field and laboratory studies on the survival and spawning of several species of gastropoda in calcium-poor and calcium-rich waters. Proceedings of the Malacological Society of London, v. 41, p. 429437, 1975. 